\title{
Movements and Inferred Foraging by Bowhead Whales in the Canadian Beaufort Sea during August and September, 2006-12
}

\author{
Lois A. Harwood, ${ }_{1}^{1}$ Lori T. Quakenbush, ${ }^{2}$ Robert J. Small, ${ }^{3}$ J. Craig George, ${ }^{4}$ James Pokiak, ${ }^{5}$ Charles Pokiak, ${ }^{6}$ \\ Mads Peter Heide-Jørgensen, ${ }^{7}$ Ellen V. Lea ${ }^{8}$ and Harry Brower ${ }^{4}$
}

(Received 30 June 2016; accepted in revised form 31 October 2016)

\begin{abstract}
Each spring, most bowhead whales of the Bering-Chukchi-Beaufort (BCB) population migrate to the southeast Beaufort Sea and summer in Canadian waters. In August and September, they form aggregations, which are known to occur mainly in the shallow, shelf waters when oceanographic conditions promote concentration of their zooplankton prey. The movements of individual bowheads while they occupy these late summer habitats are less well known; our knowledge is based on photographic evidence and limited tagging studies conducted from 1982 to 2000. In this study, 85\% (17) of the 20 satellite-tagged whales that could have spent some time in the Canadian portion of the Beaufort Sea during late summer 2006 to 2012 spent all or part of August and September there. We analyzed location data for 16 whales, using a two-state switching correlated random walk (CRW) behavioural model, and classified locations in the Canadian waters as associated with lingering behaviour (inferred foraging) or directed travel. We found that these whales spent the greatest proportion of their time lingering (59\%), followed by traveling (22\%), and transitioning between lingering and traveling (19\%). Using only lingering locations for these tagged whales in all study years pooled, we calculated kernel densities and defined five areas within the $75 \%$ density contour as aggregation areas. Together, the five aggregation areas we defined comprised $25341 \mathrm{~km}^{2}$, $14.1 \%$ of the total area used by these tagged whales in Canadian waters during August and September of the deployment years. Three aggregation areas were located in shallow waters of the Beaufort Sea Shelf and were used almost exclusively by immature tagged whales in our sample. Two other aggregation areas were observed, one in Darnley Bay and one in Viscount Melville Sound in the Canadian Arctic Archipelago. Each of these was used by one mature whale. Tagged whales were observed to use one or two aggregation areas in a single season, and rarely more. The proportion of lingering time spent in each aggregation area was highly variable among individuals. The largest aggregation area $\left(10877 \mathrm{~km}^{2}\right)$, located over the Beaufort Shelf north of the Tuktoyaktuk Peninsula (5-52 m depth), was used by 13 of the 16 tagged whales, almost exclusively by the immature whales, including three of four that were tracked in two consecutive summers. The Beaufort Shelf overall (and possibly the Tuktoyaktuk Shelf, including the Outer Shelf, in particular) was especially important for immature bowhead whales, while mature whales used habitats beyond the Beaufort Shelf during late summer. Findings may be important to inform both decisions on management and mitigative actions relating to bowhead whale use of the Beaufort Shelf and studies that aim to improve our understanding of the prey base of $\mathrm{BCB}$ bowhead whales in the Canadian Beaufort Sea region.
\end{abstract}

Key words: bowhead whale; aggregation areas; Beaufort Sea; Amundsen Gulf; Viscount Melville Sound; Darnley Bay; inferred foraging; Balaena mysticetus; satellite-linked telemetry

RÉSUMÉ. Tous les printemps, la plupart des baleines boréales de la population de Béring-Tchouktches-Beaufort (BCB) migrent vers le sud-est de la mer de Beaufort et passent l'été dans les eaux canadiennes. En août et en septembre, elles forment des agrégations, principalement dans les eaux de plateau peu profondes lorsque les conditions océanographiques favorisent la concentration du zooplancton, qui leur sert de proie. Individuellement, les déplacements des baleines boréales qui occupent ces habitats en fin d'été sont moins connus. Nos connaissances sont fondées sur des preuves photographiques ainsi que sur des études de marquage restreint réalisées entre 1982 et 2000. Dans le cadre de la présente étude, $85 \%$ (17) des 20 baleines pistées par satellite qui auraient pu passer du temps dans la partie canadienne de la mer de Beaufort vers la fin de l'été de 2006 à 2012 y ont passé les mois d'août et de septembre, en totalité ou en partie. Nous avons analysé les données de localisation de 16 baleines à l'aide d'un modèle de comportement de marche aléatoire corrélée à commutation binaire, et classé les localisations

${ }^{1}$ Corresponding author: Department of Fisheries and Oceans, Science, 3015204 50th Avenue, Yellowknife, Northwest Territories X1A 1E2, Canada; lois.harwood@dfo-mpo.gc.ca

${ }^{2}$ Alaska Department of Fish and Game, Fairbanks, Alaska 99708, USA

${ }^{3}$ Alaska Department of Fish and Game, 1255 West 8th Street, Juneau, Alaska 99811, USA

${ }^{4}$ North Slope Borough Department of Wildlife Management, PO Box 69, Barrow, Alaska 99723, USA

${ }^{5}$ Box 131, Tuktoyaktuk, Northwest Territories X0E 1C0, Canada

${ }^{6}$ Box 379, Tuktoyaktuk, Northwest Territories X0E 1C0, Canada

${ }^{7}$ Greenland Institute of Natural Resources, Strandgade 91, 3, Postboks 2151, DK-1016 Copenhagen, Denmark

${ }^{8}$ Department of Fisheries and Oceans, Box 1871, Inuvik, Northwest Territories X0E 0T0, Canada

(C) The Arctic Institute of North America 
dans les eaux canadiennes comme relevant d'un comportement de traînage (présupposition de comportement d'alimentation) ou comme relevant de déplacements orientés. Nous avons constaté que ces baleines passaient la plus grande partie de leur temps à traîner (59 \%), à se déplacer (22 \%), et à faire la transition entre traîner et se déplacer (19 \%). En n'utilisant que les localisations de traînage des baleines pistées pour toutes les années à l'étude, nous avons calculé les noyaux de densité et défini cinq zones à l'intérieur du contour de la densité de $75 \%$ à titre de zones d'agrégation. Ensemble, les cinq zones d'agrégation que nous avons définies s'étendent sur $25341 \mathrm{~km}^{2}$, soit 14,1\% de la zone totale utilisée par ces baleines pistées dans les eaux canadiennes en août et en septembre des années de déploiement. Trois zones d'agrégation étaient situées dans les eaux peu profondes du plateau de la mer de Beaufort, et ces zones étaient principalement utilisées par les baleines immatures pistées dans notre échantillon. Deux autres agrégations ont été observées, une dans la baie Darnley et l'autre dans le détroit du Vicomte de Melville situés dans la partie canadienne de l'archipel Arctique. Chacun de ces endroits était utilisé par une baleine adulte. Des baleines pistées ont été aperçues dans une ou deux zones d'agrégation au cours d'une même saison, rarement plus. La proportion du temps passé à traîner dans chaque zone d'agrégation variait beaucoup d'un individu à l'autre. La plus grande zone d'agrégation $\left(10877 \mathrm{~km}^{2}\right.$ ), située sur le plateau de la mer de Beaufort au nord de la péninsule de Tuktoyaktuk (d'une profondeur de 5 à $52 \mathrm{~m}$ ), était utilisée par 13 des 16 baleines pistées, presque toujours des baleines immatures, dont trois sur quatre ont été repérées pendant deux étés consécutifs. Dans l'ensemble, le plateau de la mer de Beaufort (et peut-être le plateau de Tuktoyaktuk, y compris la zone externe du plateau, en particulier) revêtait une importance particulière pour les baleines boréales immatures, tandis que les baleines adultes se servaient des habitats situés au-delà du plateau de la mer de Beaufort vers la fin de l'été. Ces constatations pourraient jouer un rôle important quand vient le temps d'éclairer tant les décisions en matière de gestion et de mesures d'atténuation se rapportant à l'utilisation que fait la baleine boréale du plateau de la mer de Beaufort que les études visant à améliorer notre compréhension de la composition des proies des baleines boréales de BCB dans la région canadienne de la mer de Beaufort.

Mots clés : baleine boréale; zones d'agrégation; mer de Beaufort; golfe Amundsen; détroit du Vicomte de Melville; baie Darnley; présupposition de comportement d'alimentation; Balaena mysticetus; télémétrie satellitaire

Traduit pour la revue Arctic par Nicole Giguère.

\section{INTRODUCTION}

Each spring, most bowhead whales (Balaena mysticetus) of the Bering-Chukchi-Beaufort $(\mathrm{BCB})$ population migrate to the southeast Beaufort Sea in Canadian waters, where they form aggregations during August and September (Richardson et al., 1987; Harris et al., 2007, 2008; Harwood et al., 2009; Walkusz et al., 2012; Citta et al., 2015). Bowheads first arrive in the southeast Beaufort Sea and Amundsen Gulf (Fig. 1) in late May and early June (Moore and Reeves, 1993; Quakenbush et al., 2012; Clark et al., 2015). As the open water season progresses, most whales move westward, and by July, they tend to be widely distributed over the Beaufort Sea Shelf offshore of the Tuktoyaktuk Peninsula and Mackenzie River estuary and throughout Amundsen Gulf (Davis et al., 1982; Harwood and Borstad, 1985; Richardson et al., 1987; Moore and Reeves, 1993; Charif et al., 2013; Citta et al., 2015). In early to mid-August, oceanographic conditions promote concentration of the bowhead's planktonic prey (Griffiths and Buchanan, 1982; Thomson et al., 1986; Bradstreet et al., 1987; Ashijan et al., 2010; Okkonen et al., 2011; Walkusz et al., 2012; Citta et al., 2015), and this period coincides with the time when bowheads form aggregations that generally persist through most of September (Richardson et al., 1987; Harwood et al., 2009; Walkusz et al., 2012), foraging being the predominant behaviour observed at this time of year (Würsig et al., 1985, 1989).

Studies using ship and aerial platforms in the 1980s, 1990s, and 2000s showed that bowheads form aggregations mainly in shallow, shelf waters of the eastern Beaufort Sea during August and September (Cubbage and Calambokidis, 1987; Richardson et al., 1987; Koski et al., 1988; Würsig et al., 1989; Moore and Reeves, 1993; Richardson and Thomson, 2002; Harris et al., 2007, 2008; Harwood et al., 2009; Koski and Miller, 2009). These areas include waters adjacent to Cape Parry and Cape Bathurst and the shallow shelf waters off the Tuktoyaktuk Peninsula and the Mackenzie River estuary, along the Yukon coast, and near Herschel Island (Richardson et al., 1987; Koski et al., 1988; Harwood et al., 2009; Walkusz et al., 2012). The ephemeral oceanographic and meteorological processes that promote the concentration of the bowhead's planktonic prey are believed to underpin changes in the timing, location, and size of areas that are attractive to bowheads, both within and among years (Griffiths and Buchanan, 1982; Thomson et al., 1986; Bradstreet et al., 1987; Richardson and Thomson, 2002; Walkusz et al., 2012). Further research is needed to better describe the spatial and temporal distribution of bowhead prey in the Canadian Beaufort Sea, particularly in aggregation areas, and the oceanographic and meteorological processes that promote, sustain, and influence production and concentration of prey in the feeding areas.

Previous studies have shown that bowheads aggregate on the Beaufort Shelf. However, little is known about day-to-day movements of individuals among areas within years, or whether they are faithful to areas across years. Photographic studies have found that bowheads were segregated by size class on their late summer range 


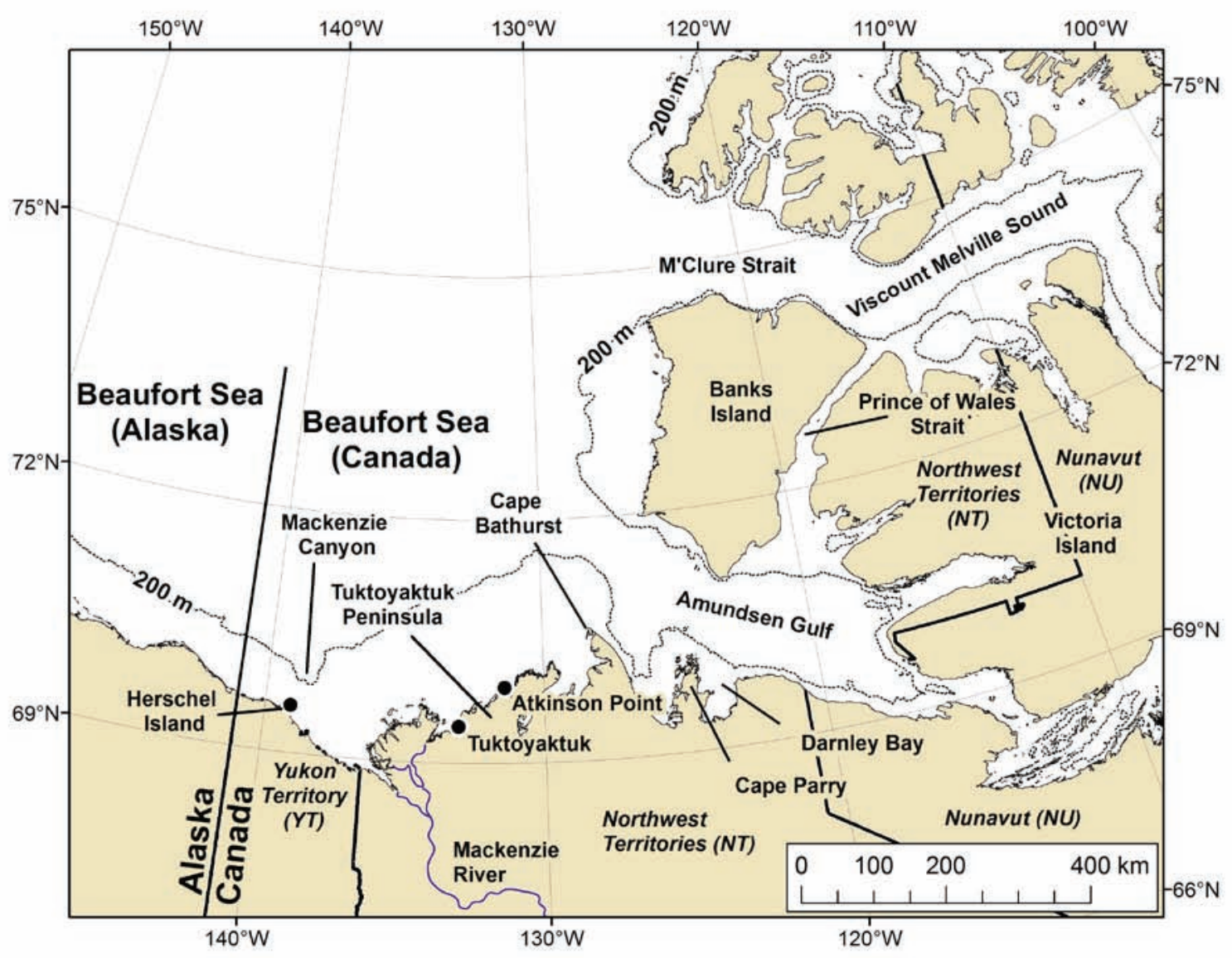

FIG. 1. Study area for satellite-tagged bowhead whales in the southeast Beaufort Sea region.

and documented seasonal and inter-year repeated use of aggregation areas, particularly by mature adults (Koski et al., 1988; Richardson and Thomson, 2002; Koski and Miller, 2009). In September of 1992, Mate et al. (2000) attached satellite-linked transmitters to eight immature whales in an aggregation area in Mackenzie Bay and tracked them for 3-24 days. Although the small number of whales tagged and the short tracking period precluded evaluation of region-wide patterns of habitat use, some of the tagged whales were observed to visit (i.e., at least pass by) aggregation areas identified during aerial surveys flown in other years, such as Mackenzie Canyon and Yukon coastal waters in particular (Richardson et al., 1987; Richardson and Thomson, 2002; Miller et al., 2005; Harwood et al., 2009).

Our study objectives were to analyze satellite tracking data obtained from 20 bowhead whales from 2006 to 2012 and to describe the whales' movements while in the Canadian Beaufort Sea during late summer. We identified the areas where tagged bowheads aggregated and examined both movements of individuals among aggregation areas within years and the tendency for individuals to use aggregation areas in successive years. The present analysis is the first to focus only on movements of whales in the Canadian Beaufort Sea region. The data analyzed here are a subset from a larger telemetry project, conducted cooperatively with Inupiat and Inuvialuit subsistence whalers from both Canada and Alaska (Quakenbush et al., 2010a; Citta et al., 2012, 2014, 2015; Heide-Jørgensen et al., 2012; Christman et al., 2013; ADFG, 2016).

\section{METHODS}

\section{Tag Deployment}

We used the satellite-linked transmitter attachment and deployment system developed by the Greenland Institute of Natural Resources (Heide-Jørgensen et al., 2001, 2003) to deploy tags on bowhead whales and the Argos system of satellites to obtain data from the tags. Tags were secured to the end of a wooden harpoon $(2 \mathrm{~m})$ or a fiberglass pole $(4 \mathrm{~m})$. Tags were deployed during a final close approach in a 6.5-7 $\mathrm{m}$ boat, from a distance of 4 to $10 \mathrm{~m}$ from the whale (see Quakenbush et al., 2010b for further details).

We deployed SPOT and SPLASH tags manufactured by Wildlife Computers (Redmond, Washington), which were attached to the whale by means of a $\sim 20 \mathrm{~cm}$ long anchor implanted through the skin and into the blubber layer. The stainless steel anchor consists of a central rod with 2-3 flexible, flat barbs alternately fixed along the rod. The barbs are designed to splay out with any outward pull on the tag 
to hold the tag in the blubber layer. Maximum penetration is restricted to the outer $20 \mathrm{~cm}$ of blubber.

The pole and harpoon also include a tip designed to collect a skin sample during tag deployment. Skin biopsies were used to determine sex of whales using the polymerase chain reaction to amplify either zinc finger (ZFX and ZFY) genes (Morin et al., 2005) or USP9X and USP9Y genes (Bickham et al., 2011), both of which are sex-determining regions within bowhead whale DNA. Subsistence whalers estimated whale length visually during tagging. Calves less than one year of age and cows with calves were avoided, as per the terms of our scientific research permits.

\section{Data Analysis}

State-Space Estimation of Whale Location and Behaviour: We used a two-state switching correlated random walk (CRW) model, as described in Jonsen et al. (2005) and Breed et al. (2009), to fit all location data obtained from 2006 to 2012 from 20 satellite-tagged bowhead whales. We used this CRW model to take irregularly received satellite location data and statistically estimate the geographic locations of the tagged whale at six-hour intervals. The model accounted for location error in the original satellite locations and used two sets of movement parameters, one set associated with lingering behaviour and the other associated with directed movements. In practice, the model works well with tracking data for bowhead whales because they generally travel directly to a specific area where they "zig-zag" for multiple days or even months (e.g., Quakenbush et al., 2013).

We first calculated an observation index that relates irregularly observed locations to regular time steps within the CRW model (see Jonsen et al., 2005). After calculating the observation index, we then used it in the transition equation:

$$
\mathrm{d}_{t} \sim \gamma T d_{t-1}+N_{2}(0, \Sigma),
$$

where $\mathrm{d}_{t-1}$ and $\mathrm{d}_{t}$ are two-element vectors representing the difference in latitude and longitude between successive locations; $\mathrm{d}_{t-1}$ represents the distance between locations $\mathrm{x}_{t-1}$ and $\mathrm{x}_{t-2}$, and $\mathrm{d}_{t}$ represents the distance between locations $\mathrm{x}_{t}$ and $\mathrm{x}_{t-1} . T$ is a transition matrix that relates the turn angle to the spherical latitude-longitude coordinates of the data and location estimates:

$$
\mathbf{T}(\theta)=\left[\begin{array}{cc}
\cos \theta & -\sin \theta \\
\sin \theta & \cos \theta
\end{array}\right],
$$

where $\theta$ is the mean turn angle in radians. The correlation coefficient, $\gamma$, autocorrelates both direction of travel (i.e., $\theta$ ) and speed. Values of $\gamma$ near 1 are always associated with values of $\theta$ near $0 . N_{2}$ represents the randomness in the animal's behaviour and is modeled with a bivariate normal distribution with mean 0 and covariance matrix:

$$
\Sigma=\left[\begin{array}{cc}
\sigma_{\text {lon }}^{2} & \rho \sigma_{\text {lon }} \sigma_{\text {lat }} \\
\rho \sigma_{\text {lon }} \sigma_{\text {lat }} & \sigma_{\text {lon }}^{2}
\end{array}\right],
$$

where $\sigma_{l o n}^{2}$ is the variance in longitude, $\sigma_{l a t}^{2}$ is the variance in latitude, and $\rho$ is the correlation coefficient between the two.

The model switches between two behavioural states, represented by two sets of parameters for $\gamma$ and $\theta$. Because these parameters are correlated, we can use just one of them to indicate behavioural state. Migratory behaviours are associated with high autocorrelation (values of $\gamma$ near 1) and low turn angles (values of $\theta$ near 0 ). We follow Jonsen et al. (2005) in using $\theta$ to indicate behavioural state; additional details and code for modeling that we used are provided by Jonsen et al. (2005) and Breed et al. (2009). We used the Markov Chain Monte Carlo (MCMC) method in WinBUGS 1.4 (available online). We estimated movement parameters by running two chains, each with 20000 iterations. The first 10000 iterations were discarded, resulting in 10000 samples from each chain (20000 samples total) to estimate mean latitude, longitude, and behavioural state for each six-hour interval for each whale. Behavioural state is modeled as a binary variable that is time-specific. Variation in behavioural state comes from separate iterations of the MCMC process used to describe parameter distributions. Behavioural state had values ranging from 1 to 2 . We classified locations with values below 1.25 as "directed travel" and values above 1.75 as "lingering." Transitional values (1.25 to 1.75$)$ are of uncertain state and were not included in the spatial analyses. Vague priors were used for all parameters; we used a uniform prior for $\theta$, a Wishart prior for " $\sum$," and a beta prior for $\gamma$. Within the observation equation, we use the same error distributions for Argos location quality classes used by Jonsen et al. (2005).

The model predicts the true location of an animal within intervals for which there are no satellite location data. Although these predictions are usually reasonable if the gap in data collection is not too long, we used estimated locations and their behavioural state only from intervals in which satellite data were collected. If no data were collected within a six-hour interval, the estimated location and behavioural state were not used for analysis. Prior to modeling the data, we removed extreme outliers that were more than $300 \mathrm{~km}$ from where whales could be located, as these points lie outside the location error distributions that are typically used with state-space modeling. After modeling, we removed estimated locations that fell on land.

Areas of Aggregation (Kernel Density Estimation): We used kernel densities (e.g., Silverman, 1986; Worton, 1989; Wand and Jones, 1995) to define the spatial extent of geographic areas where bowheads aggregated. Kernel density estimation is a non-parametric method for calculating the probability that an animal occurs within each point in space. Following Quakenbush et al. (2010b) and Citta et al. (2012), we selected a bandwidth matrix for each whale using smoothed cross-validation (Duong and 
Hazelton, 2005) as calculated by package "ks" (Duong, 2007) in R version 2.11.1 (R Development Core Team, 2010). Because we have a limited sample of whales and did not want to misrepresent the point patterns, we estimated separate bandwidths for the $\mathrm{x}$ and $\mathrm{y}$ dimensions, but not the full covariance matrix. As recommended by Duong and Hazelton (2005), we pre-scaled our data before calculating bandwidth matrices.

We calculated two kernel densities from the state-space data. First, we calculated the density of all August and September locations in the Canadian Beaufort Sea region, using locations of all behavioural states (i.e., those classified as "lingering," "directed travel," and "transitional"). Some proportion of the lingering we observed would have also included socializing and resting (Würsig et al., 1985, 1989). We then calculated the density of August and September "lingering" locations, excluding locations classified as "directed travel" or "transitional." We defined the areas of aggregation as occurring within the $75 \%$ density contour of lingering locations. Few whales were tagged in most years, so we could not calculate separate kernel densities by year, and this necessitated pooling all years and calculating a single kernel density. Bathymetric data were obtained from Jakobsson et al. (2012) to calculate the mean and range of water depths in each aggregation area that we defined.

\section{RESULTS}

In this paper, we examine where bowhead whales occur during the months of August and September, focusing on Canadian waters east of $141^{\circ} \mathrm{W}$ longitude (Fig. 1). From the overall program (ADFG, 2016), there were 20 satellitetagged bowhead whales (Table 1) that transmitted during the months of August and September. Of these, 13 were tagged in Canadian waters in late summer (mid-August to early September, all but one on the Tuktoyaktuk Shelf), and seven in Alaskan waters, four in spring (April-May) and three in late summer to early fall (August-October).

The August-September estimated locations for the 20 whales are shown on Figure 2, with deployments spanning the years from 2006 to 2012. Four were tracked for two consecutive August-September periods. During August and September, the number of known calendar days that these tagged bowheads were in Canadian waters averaged $24.5 \mathrm{~d}$ (SD $18.1 \mathrm{~d}$; range $0-61 \mathrm{~d}$ ) (Table 1). This number is biased low, however, because 13 whales were tagged in Canada during late August or early September: since aggregations can form at least as soon as early August, these whales had already been present for days or weeks prior to tagging (e.g., 2008, see Harwood et al., 2009). Also, in four cases, tags stopped transmitting while the whales were in Canadian waters in August or September, so these whales too were likely present for a longer time (Table 1).

All but three of the 20 tagged whales spent time in Canadian waters during August or September. One whale that did not was B09-09, tagged near Barrow, Alaska, on 29 August 2009. Although this tag transmitted for almost a year, going off the air on 1 August 2010, the whale summered in the Chukchi Sea and did not enter the Canadian Beaufort in 2010 (Citta et al., 2012). The other two whales, B08-07 and B10-03, migrated to the Canadian Beaufort Sea in the spring of the tag deployment year, but moved back west into the Alaskan Beaufort prior to August, in both cases leaving the Canadian Beaufort Sea altogether in July (on 29 July 2009 and 13 July 2010, respectively). Additionally, one whale (B10-09) was tagged near Herschel Island in August 2010, but this whale was not included in our habitat use analyses because only a single lingering location was obtained before the tag stopped transmitting.

Thus, we used locations from 16 whales for our habitat use analysis in Canadian waters during August and September in 2006 to 2012. Including all behavioural states for these 16 whales, the size of the $99 \%$ kernel density contour in Canadian waters was $179672 \mathrm{~km}^{2}$. During August and September, these whales on average spent 59\% of their time lingering, 22\% traveling, and 19\% in transition between these states (Table 2).

\section{Size, Location, and Use of Aggregation Areas}

Using only locations associated with lingering, the $99 \%$ kernel density contour included $79140 \mathrm{~km}^{2}$. Within this area, we defined the $75 \%$ density contour $\left(25341 \mathrm{~km}^{2}\right.$ in total) to be areas of aggregation, and found five such "aggregation areas": Mackenzie Shelf, Tuktoyaktuk Shelf, Outer Shelf, Darnley Bay, and Viscount Melville Sound (VMS) (Table 3, Fig. 3). Although the Tuktoyaktuk Shelf and the Outer Shelf share a section of the same $75 \%$ contour line, we separated them into two aggregation areas, one over the shallow shelf $(<50 \mathrm{~m})$, and one farther from shore, in deeper water (range 33-172 m) and more directly influenced by upwelling from Cape Bathurst (Walkusz et al., 2012). All five aggregation areas were located in waters less than $200 \mathrm{~m}$ deep, with the exception of VMS, which has a mean water depth of $478 \mathrm{~m}$ (Table 3). Together, the five areas of concentrated lingering made up $14.1 \%$ of the total area in Canadian waters that the tagged bowhead whales used in August and September, regardless of behavioural mode. Localized areas of use outside the aggregation areas were largely adjacent to these; they included Yukon coastal waters and waters offshore of Herschel Island and between Banks and Victoria Islands (Fig. 3), and they were well matched to areas used in some (but not all) years in the 1980s (see Richardson and Thomson, 2002).

Three of the aggregation areas were located west of Cape Bathurst, two over the Beaufort Shelf north of the Tuktoyaktuk Peninsula, and a third over the Beaufort Shelf seaward of the Mackenzie River estuary (Fig. 3). The largest was located off the Tuktoyaktuk Peninsula (10877 km² , 5-52 m depth; Table 3) and was used mainly (for $71.6 \%$ of the lingering intervals) by immature whales (11 of 12 tagged offshore of the Tuktoyaktuk Peninsula; Table 4). Only two of the seven whales tagged in Alaska, 


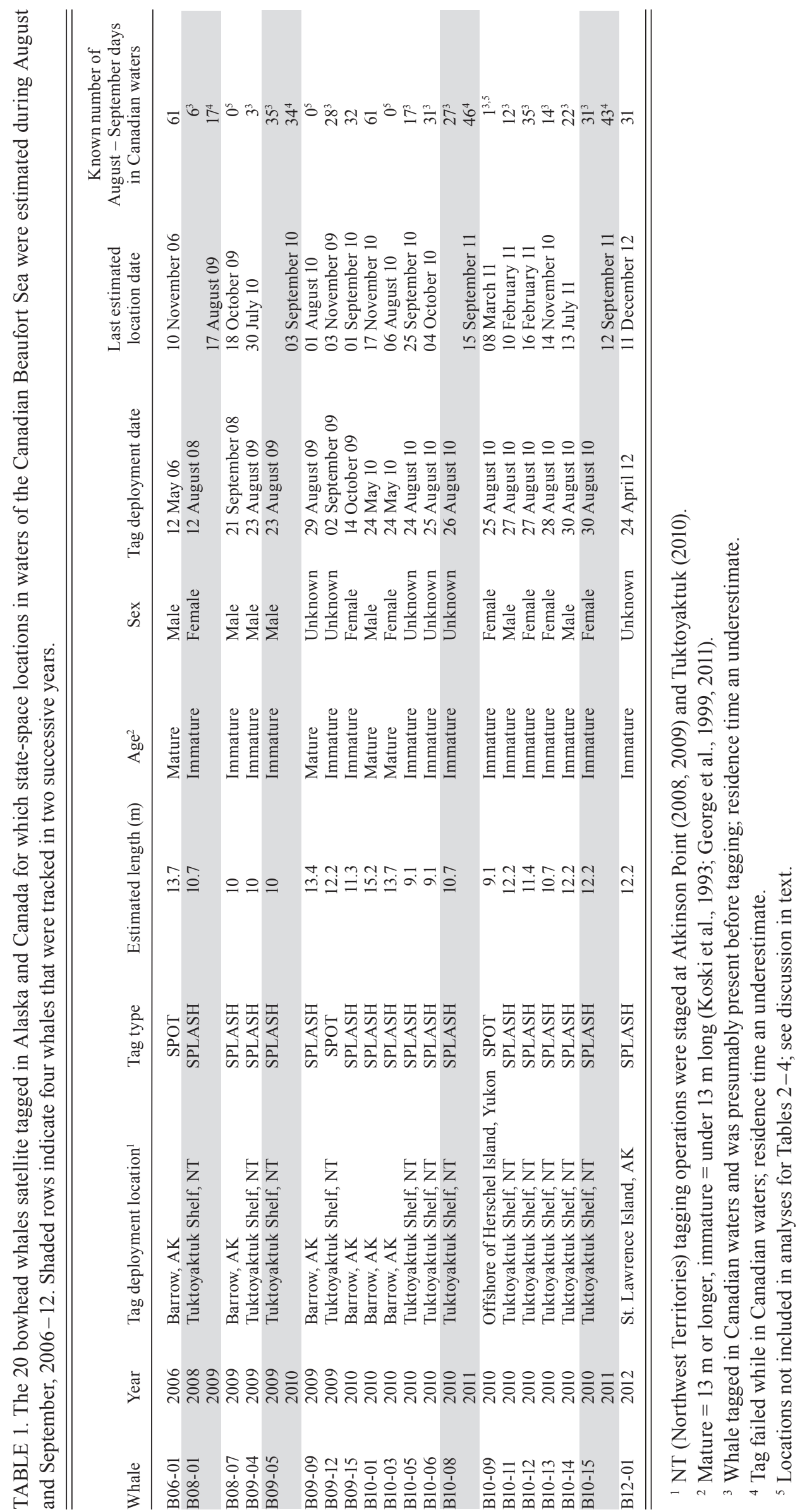




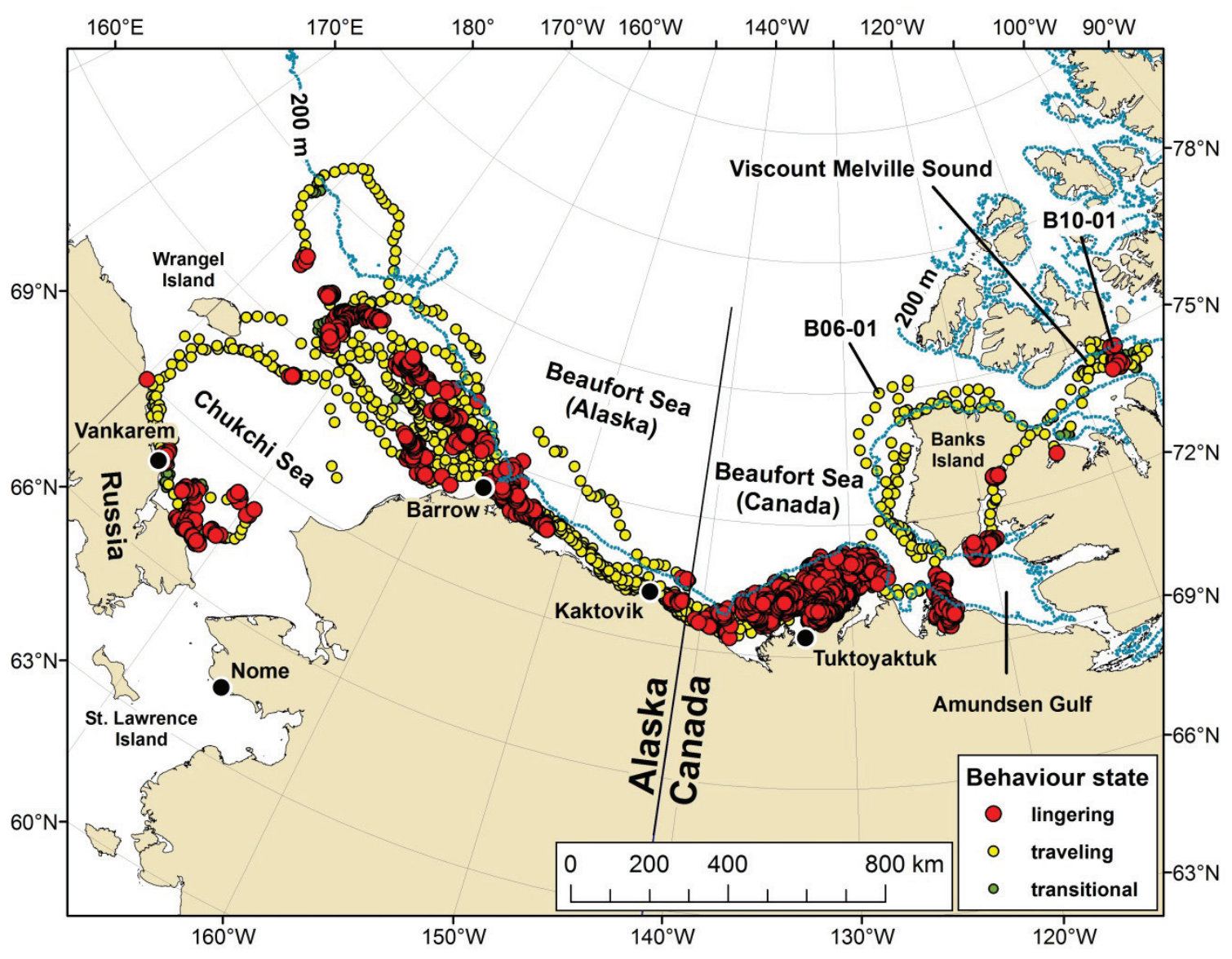

FIG. 2. Locations and associated behavioural states of bowhead whales (listed in Table 1) in August and September, 2006-12, estimated from satellite telemetry data using a state-space model.

one mature and one immature, were observed to linger in this aggregation area; in both cases, the amount of time they were observed there was minimal $(5.1 \%$ of their combined lingering intervals) (Table 4).

Six of the 12 immature bowheads tagged in the Tuktoyaktuk Shelf area also visited and lingered in the Mackenzie Shelf aggregation area $\left(6162 \mathrm{~km}^{2} ; 8-78 \mathrm{~m}\right.$ depth; Fig. 3), which had $19.4 \%$ of the total AugustSeptember lingering intervals for immature bowheads that were tagged there (Table 4). None of the Alaska-tagged whales were observed lingering in this area during August or September.

The third shelf aggregation area, the "Outer Shelf," was located farther north of the Tuktoyaktuk Peninsula and included deeper parts of the continental shelf and slope, north of the Tuktoyaktuk Peninsula and northwest of Cape Bathurst (33-172 m depth) (Table 3). While this area was used by five of 12 immature whales tagged in the Tuktoyaktuk Shelf area, the amount of time they were observed lingering there was limited $(1.4 \%$ of the lingering intervals) (Table 4). This area was used more extensively by four of seven whales tagged in Alaska: two immature and two mature whales (Table $4 ; 37.9 \%$ of their combined lingering intervals).
Each of the two remaining aggregation areas, Darnley Bay (5-169 m depth) and VMS (416-503 m depth) (Tables 3,4 ) was used by a single whale; both these whales were mature males tagged in Alaska (Table 1). Tracks for both of these whales are presented in detail in HeideJørgensen et al. (2012). B06-01 remained in Darnley Bay for more than two weeks ( $52.4 \%$ of its lingering time) and also used the Tuktoyaktuk Shelf (10.5\% of lingering time) and Outer Shelf (12.1\% of lingering time). B10-01 lingered in the VMS area, within the $75 \%$ contour area, for only $7.3 \%$ of its lingering intervals; however, this whale was present within the general area of VMS for 25 calendar days (21 August 2010 to 15 September 2010).

The large majority $(84 \%)$ of tagged bowheads were observed to use either one $(n=7)$ or two $(n=9)$ of the aggregation areas, and the remaining whales $(\mathrm{n}=3)$ used three areas (Table 4). The proportion of lingering time spent in specific aggregation areas was highly variable among individuals (Table 4). Some whales moved between aggregation areas (Fig. 4, Table 3), and in some cases, revisited the same aggregation area more than once. Of the four immature whales tracked in two consecutive summers, three used at least one of the same aggregation areas in both years, suggesting some degree of site fidelity in successive years (Fig. 5). 
TABLE 2. Statistics for the number of six-hour intervals for which behaviour states were possible and obtained for 16 bowhead whales tagged and tracked in the Canadian Beaufort Sea region in 2006-12. Shaded rows indicate whales present in August-September of two successive years, each of which is treated as an independent sample for summary statistics.

\begin{tabular}{|c|c|c|c|c|c|c|c|c|}
\hline \multirow[b]{3}{*}{ Whale } & \multirow[b]{3}{*}{ Year } & \multicolumn{2}{|c|}{ Possible $6 \mathrm{~h}$ intervals } & \multirow{3}{*}{$\begin{array}{c}\text { No. of } \\
\text { lingering } \\
\text { intervals }\end{array}$} & \multirow{3}{*}{$\begin{array}{l}\text { No. of } \\
\text { traveling } \\
\text { intervals }\end{array}$} & \multirow{2}{*}{\multicolumn{3}{|c|}{$\%$ of $6 \mathrm{~h}$ intervals with data }} \\
\hline & & & Proportion & & & & & \\
\hline & & Number & with data & & & Lingering & Traveling & Transitional \\
\hline B06-01 & 2006 & 244 & 0.92 & 124 & 81 & 55 & 36 & 8 \\
\hline \multirow{2}{*}{ B08-01 } & 2008 & 21 & 0.86 & 4 & 13 & 22 & 72 & 6 \\
\hline & 2009 & 66 & 0.47 & 12 & 5 & 39 & 16 & 45 \\
\hline B09-04 & 2009 & 148 & 0.95 & 89 & 27 & 63 & 19 & 18 \\
\hline \multirow[t]{2}{*}{ B09-05 } & 2009 & 136 & 0.94 & 76 & 25 & 59 & 20 & 21 \\
\hline & 2010 & 132 & 0.27 & 35 & 0 & 1 & 0 & 0 \\
\hline B09-12 & 2009 & 109 & 0.53 & 19 & 9 & 33 & 16 & 52 \\
\hline B09-15 & 2010 & 127 & 0.94 & 119 & 0 & 99 & 0 & 1 \\
\hline B10-01 & 2010 & 244 & 0.93 & 82 & 95 & 36 & 42 & 22 \\
\hline B10-05 & 2010 & 63 & 0.56 & 7 & 9 & 20 & 26 & 54 \\
\hline $\mathrm{B} 10-06$ & 2010 & 120 & 0.54 & 60 & 2 & 92 & 3 & 5 \\
\hline \multirow{2}{*}{$\mathrm{B} 10-08$} & 2010 & 106 & 0.99 & 45 & 19 & 43 & 18 & 33 \\
\hline & 2011 & 183 & 0.95 & 157 & 2 & 91 & 1 & 8 \\
\hline B10-11 & 2010 & 46 & 1.00 & 11 & 22 & 24 & 48 & 28 \\
\hline B10-12 & 2010 & 137 & 0.92 & 126 & 0 & 1 & 0 & 0 \\
\hline B10-13 & 2010 & 52 & 0.98 & 18 & 18 & 35 & 35 & 29 \\
\hline B10-14 & 2010 & 88 & 1.00 & 42 & 33 & 48 & 38 & 15 \\
\hline \multirow[t]{2}{*}{ B10-15 } & 2010 & 122 & 0.92 & 84 & 18 & 75 & 16 & 9 \\
\hline & 2011 & 172 & 0.99 & 151 & 0 & 89 & 0 & 11 \\
\hline \multirow[t]{3}{*}{ B12-01 } & 2012 & 121 & 1.00 & 68 & 32 & 56 & 26 & 17 \\
\hline & & & & & Mean & 59 & 22 & 19 \\
\hline & & & & & SD & 0.28 & 0.19 & 0.17 \\
\hline
\end{tabular}

TABLE 3. Size and water depth of the five aggregation areas identified using the $75 \%$ contour of locations associated with lingering behaviour (i.e., inferred feeding) within the southeast Beaufort Sea in August and September, 2006-12.

\begin{tabular}{|c|c|c|c|c|c|}
\hline \multirow[b]{2}{*}{ Aggregation area } & \multirow{2}{*}{$\begin{array}{c}\text { Area of } 75 \% \\
\text { contour }\left(\mathrm{km}^{2}\right)\end{array}$} & \multirow[b]{2}{*}{$\%$ of total area ${ }^{1}$} & \multicolumn{3}{|c|}{ Water depth (m) } \\
\hline & & & mean & $\min$ & $\max$ \\
\hline Mackenzie Shelf & 6261 & $3.5 \%$ & 37 & 8 & 78 \\
\hline Tuktoyaktuk Shelf & 10877 & $6.1 \%$ & 23 & 0 & 52 \\
\hline Outer Shelf & 6066 & $3.4 \%$ & 55 & 33 & 172 \\
\hline Viscount Melville Sound & 243 & $0.1 \%$ & 478 & 416 & 503 \\
\hline Darnley Bay & 1894 & $1.1 \%$ & 81 & 0 & 169 \\
\hline Total & 25341 & $14.1 \%$ & & & \\
\hline
\end{tabular}

${ }^{1}$ Calculated by dividing the area of the $75 \%$ contour (lingering only) by the $99 \%$ contour (all behaviours; $179672 \mathrm{~km}^{2}$ ).

In August and September, movements of tagged whales through the Shelf aggregation areas were generally from east to west (Fig. 4a). However, some whales also moved from west to east, making repeat visits to the same aggregation area in the same summer. Whale B09-04 left the Tuktoyaktuk Shelf area, moved west into the Mackenzie Shelf area, but then returned to the Tuktoyaktuk Shelf area before moving west through Yukon coastal waters (Fig. 4b). Also, one of the mature whales (B06-01) moved in a northerly direction, traveling along the west and north coasts of Banks Island and back along a similar route with no indications of lingering along the way, before it headed for the Darnley Bay area, where it remained (Fig. 2). Whale B10-01, also a mature whale, also traveled to the north, in this case through Prince of Wales Strait to VMS, with lingering detected at the entrance to and within the Strait, but not elsewhere on this track (Fig. 2).

\section{DISCUSSION}

From data for 2006-12, we identified five late summer (August-September) aggregation areas for BCB bowhead whales in the Canadian Beaufort region. These areas captured $75 \%$ of the observed lingering behaviour of 16 whales. We identified this behaviour by slow swim speeds and frequent turning, and our whales spent more than half of their time (59\%) in this state. Collectively, the five areas we defined included only $14.1 \%$ of the total area used by the tagged bowheads in Canadian waters during August and September, indicating that the areas where tagged whales focused their foraging were only a small portion of the area they traveled through.

Determining the importance of the different Beaufort Shelf aggregation areas relative to each other, and relative to other areas beyond, was constrained by where and when 


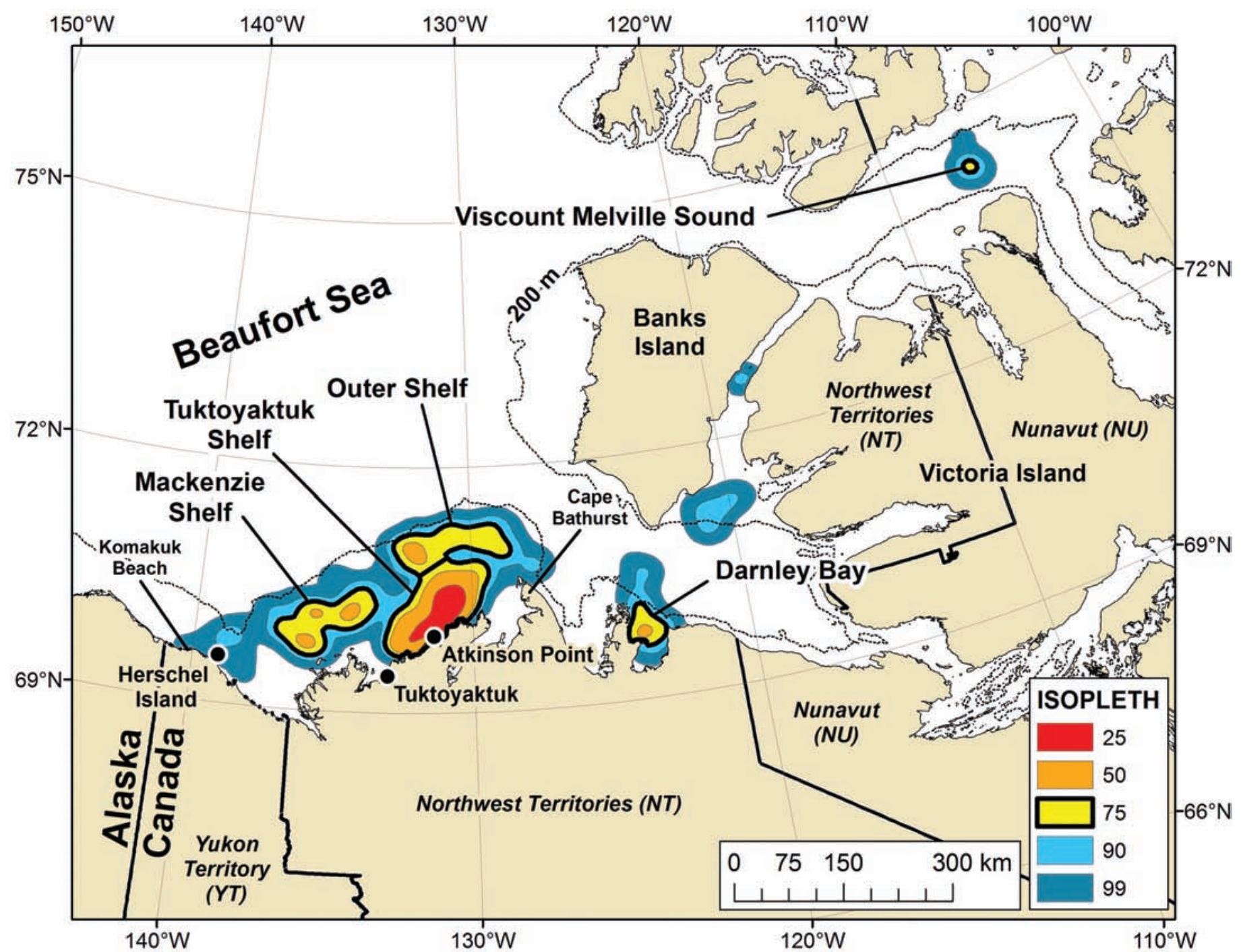

FIG. 3. The five bowhead whale aggregation areas identified using the $75 \%$ contour of locations associated with lingering behaviour (i.e., inferred foraging) within the southeast Beaufort Sea in August and September, 2006-12.

the whales were tagged, as well as by tag performance and battery life. We observed that most of the tagged bowheads used one or two aggregation areas during August and September, and appreciable movement from area to area was seen only between the Mackenzie and Tuktoyaktuk Shelf areas. Individual tagged whales stayed in the different aggregation areas for variable proportions of their lingering time. Although our sample size was quite limited, three of four whales tracked in successive years used at least one of the same aggregation areas two years in a row, corroborating evidence of repeated use that was observed in photographic studies (Koski et al., 1988; Richardson and Thomson, 2002).

Three of the aggregation areas were in shallow shelf waters seaward of the Tuktoyaktuk Peninsula and Mackenzie River estuary. These shelf aggregation areas occur in some of the same general areas where aggregations have been identified during aerial, shipboard, and acoustic studies (Richardson et al., 1987; Koski et al., 1988; Moore and Reeves, 1993; Griffiths and Thomson, 2002; Harris et al., 2007, 2008; Harwood et al., 2009; Charif et al., 2013) in some of the same years as this study.

Two aggregation areas were located beyond the Beaufort Shelf, in Darnley Bay and in VMS (Fig. 3). Little is known about how often bowheads use VMS. They were documented in Darnley Bay during photogrammetric and systematic aerial surveys in the 1980s (Davis et al., 1982; Koski et al., 1988), and subsistence hunters continue to see them there regularly (Paulatuk Hunters and Trappers Committee, pers. comm. 2012). Although each of these areas was defined by only one mature tagged whale, these two areas are probably more important than these satellite data alone reveal. When sample sizes are small, we expect that satellite-tagging studies will fail to identify all aggregation areas (e.g., Lindberg and Walker, 2007); however, areas that are identified are generally important and used by other individuals. On two separate occasions, aerial surveys flown in the vicinity of individual tagged 
170 • L.A. HARWOOD et al.

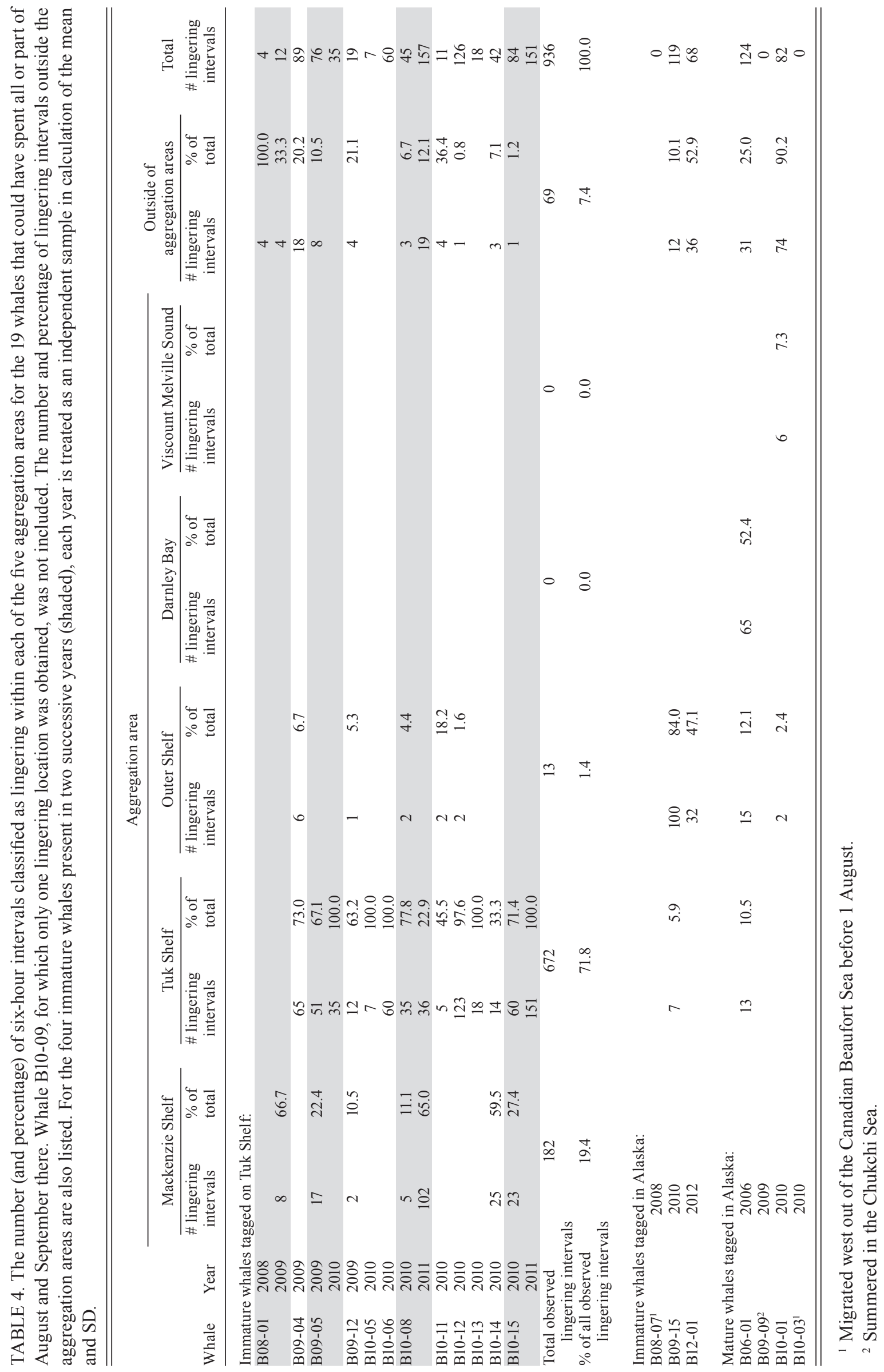



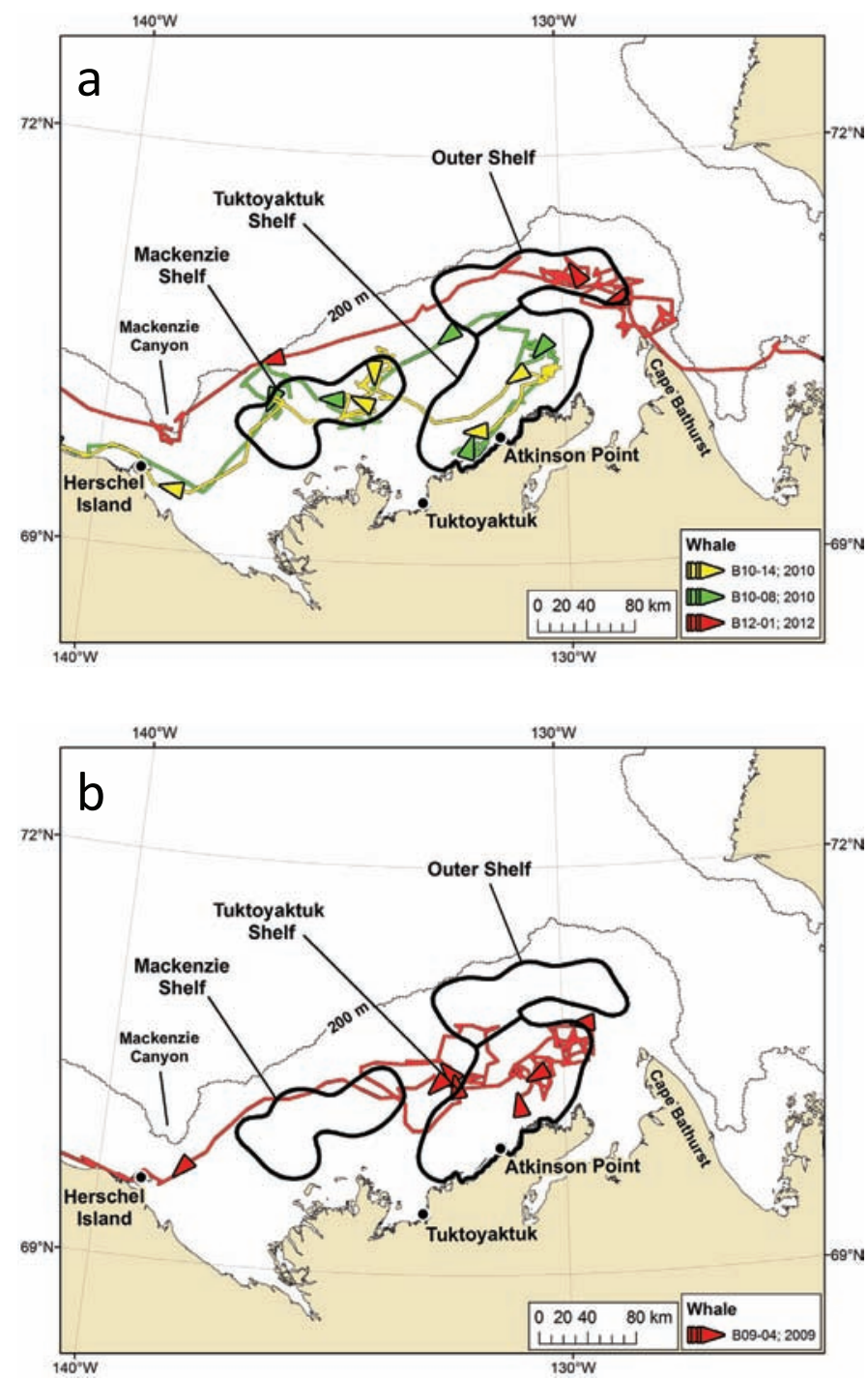

FIG. 4. Examples of the general westward movements of bowhead whales through the southeast Beaufort Sea in August and September, 2006-12. (a) Whales typically traveled from east to west through the three aggregation areas (Outer Shelf, Tuktoyaktuk Shelf, and Mackenzie Shelf). (b) One whale (B09-04) circled among the three areas.

bowhead whales located by satellite, revealed more than 10 untagged bowhead whales in the same general location. During an aerial survey in the Alaskan Beaufort Sea in July 2011, at least 18 whales were observed at the location of a tagged whale (Christman et al., 2013). Similarly, at least 10 whales were seen at the location of a tagged whale in the Mackenzie Shelf aggregation area in August 2009 (DFO, unpubl. data). Although aerial surveys have not been flown over VMS during August and September, a mature bowhead whale tagged in Greenland used the area in the same year as B10-01 (Heide-Jørgensen et al., 2012).

The general locations of the recurring aggregation areas on the Beaufort Shelf (Outer Shelf, Tuktoyaktuk Shelf, and Mackenzie Shelf) appear to be more consistent in their formation than some areas to the west (e.g., Komakuk Beach, Yukon coastal waters, Mackenzie Canyon, see Richardson et al., 1987; Richardson and Thomson, 2002;

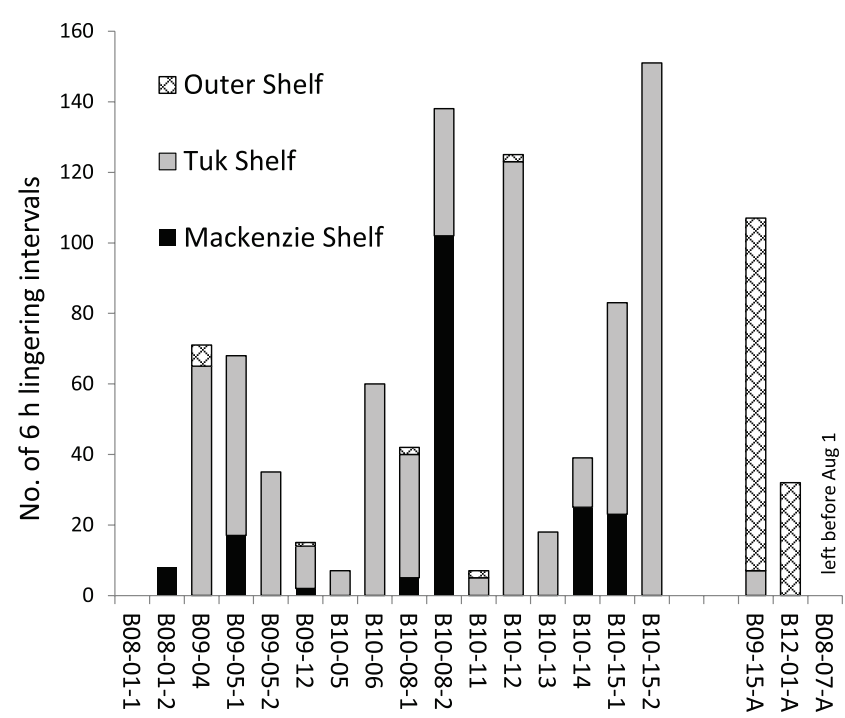

Immature Whale No.

FIG. 5. Relative use of three aggregation areas in the Canadian Beaufort Sea during August and September 2006-12 by immature bowhead whales tagged in the Tuktoyaktuk Shelf aggregation area. Those returning in a successive year are denoted with -1 and -2 after the identifying number, and three immature bowhead whales tagged in Alaska (at far right) are denoted with -A.

Harwood et al., 2009). The relative proportion of tagged whales using aggregation areas on the Tuktoyaktuk Shelf, however, is biased by their tagging location (12 of 19 were tagged in nearshore waters of the Tuktoyaktuk Shelf aggregation area), and other region-wide studies using aerial, acoustic, and shipboard methods identified similar or other bowhead aggregation areas in other years (Bradstreet and Fissel, 1987; Bradstreet et al., 1987; Richardson et al., 1987; Koski et al., 1988; Harwood et al., 2009; Walkusz et al., 2012; Charif et al., 2013), including Cape Parry (Koski et al., 1988). Thus our kernel density likely overweights the importance of the Tuktoyaktuk Shelf nearshore area to some degree, and we note that our results may not be representative of the entire population. To obtain a more representative sample, and one that could explore interannual variability, deployments on additional mature and smaller-sized immature bowheads tagged elsewhere would be necessary.

Studies of bowhead diet in Canadian waters are limited because whales from this stock are not regularly harvested in Canada. However, stomach contents from one immature whale landed in a subsistence harvest off the Yukon coast in August 1996 (Pomerleau et al., 2011), fatty acid profiling from bowheads harvested at Kaktovik, Alaska (Richardson and Thomson, 2002; Budge et al., 2008), and in situ oceanographic sampling efforts in the Canadian Beaufort Sea (Bradstreet and Fissel, 1987; Bradstreet et al., 1987; Richardson and Thomson, 2002; Walkusz et al., 2012) all point to copepods as the main prey item of bowheads while in the Canadian Beaufort Sea region.

The recurrence of the Beaufort Shelf aggregation areas results from a combination of meteorological and oceanographic conditions that reliably concentrate 
zooplankton in late summer (Harwood and Borstad, 1985; Thomson et al., 1986; Walkusz et al., 2012). For example, when they occur, easterly winds promote upwelling and advect nutrient-rich water onto the shelf near Cape Bathurst and along the shelf break (Williams and Carmack, 2008). Griffiths and Thomson (2002) and Walkusz et al. (2012) found dense aggregations of copepods (mostly Calanus glacialis and C. hyperboreus) concentrated near the seafloor in water with an upwelling signature. Shipboard and aerial observations confirmed that bowhead whales aggregated and spent time foraging in this area (Walkusz et al., 2012). Citta et al. (2015) found that tagged whales in this area spent more time near the seafloor than at other depths in $66 \%$ of dive histograms, perhaps feeding on concentrations of copepods in pre-diapause near the seafloor, as described by Walkusz et al. (2012).

Alternative prey may also be available in these shallow waters of the Beaufort Shelf. For example, there are known beds of benthic amphipods (Ampelisca spp.) on the shelf seaward of the Tuktoyaktuk Peninsula (Conlan et al., 2008, 2013) that might provide additional prey for bowhead whales. Although bowhead whales in the Beaufort Sea are thought to feed primarily on copepods, foraging on amphipods has been documented through analysis of stomach contents, and occasionally the proportion of amphipods is substantial (Lowry, 1993; Griffiths and Thomson, 2002; Lowry et al., 2004; Pomerleau et al., 2011).

The Mackenzie Shelf aggregations are located in an area strongly influenced by the brackish water plume of the Mackenzie River and adjacent to Yukon coastal waters, which are particularly productive during periods of easterly winds that promote strong upwelling (Thomson et al., 1986). Brackish waters associated with the Mackenzie Plume and Yukon coast, which particularly attract subadult bowheads in some years, are known to have concentrations of the copepod Limnocalanus macrurus (Walkusz et al., 2010) and mysids (Mysis oculata) (Bradstreet and Fissel, 1987). Large quantities of L. macrurus were found in the stomach of a subadult bowhead harvested from Yukon coastal waters in 1996 about $50 \mathrm{~km}$ west of the Mackenzie River plume (Pomerleau et al., 2011). Zooplankton upwelled and advected from deeper basin waters (e.g., C. glacialis or C. hyperboreus) are also known to aggregate along salinity fronts within the Mackenzie Shelf area (Bradstreet and Fissel, 1987; Bradstreet et al., 1987; Griffiths and Thomson, 2002).

Although our sample size of mature whales was small and all were tagged in Alaska $(\mathrm{n}=4$; Table 1$)$, mature whales appeared less likely than immature whales to summer on the Beaufort Shelf. Two mature whales traveled past the Beaufort Shelf to Darnley Bay (B06-01) and VMS (B10-01). The other two (B09-09 and B10-03) were not in the Canadian Beaufort in August and September at all, but either stayed in the Chukchi Sea or returned to the Chukchi Sea in late July. Koski et al. (1988) and Koski and Miller (2009) found mainly adults in deeper Beaufort Shelf and Amundsen Gulf habitats, while immature whales predominated in shallow $(<20 \mathrm{~m})$ nearshore areas. Our findings, although biased toward the larger subadult component of the population, are consistent with the Koski et al. (1988) findings that mature whales are less likely than immature whales to summer on the southeast Beaufort Sea Shelf.

Although little is known about the oceanographic conditions in VMS and Darnley Bay, evidence from other studies suggests that both areas are biologically productive in late summer, attracting several species of marine mammals. Ringed seals (Pusa hispida) used VMS and Darnley Bay during late summer for foraging (Harwood et al., 2015), and we know of at least one tagged bowhead whale from the Eastern Arctic-West Greenland population that used VMS in late summer 2010 (Heide-Jørgensen et al., 2012). VMS is also a summer foraging area that was used by adult male beluga whales (Delphinapterus leucas) in 1993 and 1995 (Richard et al., 2001), and Darnley Bay is also within the usual summer range of belugas (Richard et al., 2001; Hauser et al., 2014). Studies to better understand the processes that underpin this productivity would be useful, and especially timely for Darnley Bay (Paulic et al., 2012), given its 2016 designation as the Anuniaqvia Niqiqyuam Marine Protected Area under Canada's Oceans Act.

\section{CONCLUSIONS}

The Canadian Beaufort Sea Shelf, from the Mackenzie Estuary to Cape Bathurst, is clearly an important late summer feeding area for bowhead whales of the BCB population. Whales spent a large proportion of their time foraging there in relatively localized areas. However, the amount of time spent in the Beaufort Shelf aggregation areas was variable among individuals, as were their patterns of movement among aggregation areas. Mature whales appear more likely than the immature whales to use deeper water habitats beyond the Beaufort Shelf. The eastern Beaufort Shelf overall, and possibly the Tuktoyaktuk Shelf (including the Outer Shelf) in particular, appear especially important for immature bowhead whales. Habitat degradation or displacement of bowhead whales from the shelf aggregation areas may have energetic consequences for the subadult component of the population. Additional satellite telemetry is needed to better describe the late summer habitats used by mature adults, which are the least well represented in our sample.

\section{ACKNOWLEDGEMENTS}

This project involved contributions, support, and hard work from many organizations, agencies, and individuals, including the following: the Alaska Eskimo Whaling Commission, the North Slope Borough (Billy Adams, Robert Suydam, and Taqulik Hepa), the Barrow and Kaktovik Whaling Captains Associations 
(Eugene Brower, Fenton Rexford, Joe Kaleak, George Tagarook, and Eddie Arey), the Barrow Arctic Science Consortium (Lewis Brower), the Aklavik and Tuktoyaktuk Hunters and Trappers Committees (Dennis Arey, Larry Arey, Pat Kasook, Danny C. Gordon, Buddy Gruben, Douglas Panaktalok, Mikkel Panaktalok, Max Kotokak, Sr.), the Department of Fisheries and Oceans Canada (DFO; Kevin Bill, Tim Leblanc, Andrew Nichols, Patrick Ryan, Terry Stein, Angus Alunik), Dr. Stephen Raverty of the British Columbia Animal Health Center, and the Greenland Institute of Natural Resources (Mikkel Jensen, Anders Villum Jensen). We are grateful to Dr. John Citta of the Alaska Department of Fish and Game (ADFG) for database management and modeling the data.

Funding for this research was provided mainly by the U.S. Minerals Management Service (now the Bureau of Ocean Energy Management) under contracts M12PC00005, M10PS00192, and 01-05-CT39268, with support and assistance from Charles Monnett, Jeffery Denton, and Carol Fairfield, and under Interagency Agreement No. M08PG20021 with NOAA-NMFS and Contract No. M10PC00085 with the ADFG. Work in Canada was also funded by the Fisheries Joint Management Committee, the Ecosystem Research Initiative (DFO), the Species at Risk Recovery Strategy (DFO) under the Species at Risk Act (SARA), and the Panel for Energy Research and Development (PERD). Bowhead whale research was conducted in the United States under a Marine Mammal Protection Act permit issued to the National Marine Fisheries Service (No. 782-1719) and to the ADFG (No. 14610) and under Animal Care and Use Permit Nos. 06-16, 09-21, 10-13R, 12-020. In Canada, research was conducted under DFO Scientific License Nos. S-07/08-4007-IN, S-08/094000-IN, S-09/10-4005-IN-A1 and S-10-11 318- YK, and Animal Care Protocols FWI-ACC-2007-2008-013, FWI-ACC-2008-031, FWI-ACC-2009-019 and FWI-ACC-2010-034. We thank Janet Clarke, Lloyd Lowry, and Dr. John Richardson for helpful reviews of this manuscript.

\section{REFERENCES}

ADFG (Alaska Department of Fish and Game). 2016. Bowhead whale research: Satellite tracking of Western Arctic bowhead whales.

http://www.adfg.alaska.gov/index.cfm?adfg=marinemammal program.bowhead

Ashjian, C.J., Braund, S.R., Campbell, R.G., George, J.C., Kruse, J., Maslowski, W., Moore, S.E., et al. 2010. Climate variability, oceanography, bowhead whale distribution and Iñupiat subsistence whaling near Barrow, Alaska. Arctic 63(2):179-194.

https://doi.org/10.14430/arctic973

Bickham, J.W., Downing, H.K., Patton, J.C., George, J.C., and Suydam, R.S. 2011. Molecular assessment of sex chromosome polymorphisms in the bowhead whale. International Whaling Commission SC/63/BRG14. 9 p.
Bradstreet, M.S.W., and Fissel, D.B. 1987. Zooplankton of a bowhead whale feeding area off the Yukon coast in August 1985, Part 2. In: Bowhead whale food availability characteristics in the southern Beaufort Sea: 1985 and 1986. Environmental Studies 50. Ottawa: Indian and Northern Affairs Canada. 229-408.

Bradstreet, M.S.W., Thomson, D.H., and Fissel, D.B. 1987. Zooplankton and bowhead whale feeding in the Canadian Beaufort Sea, 1986, Part 1. In: Bowhead whale food availability characteristics in the southern Beaufort Sea: 1985 and 1986. Environmental Studies 50. Ottawa: Indian and Northern Affairs Canada. 9-228.

Breed, G.A., Jonsen, I.D., Myers, R.A., Bowen, W.D., and Leonard, M.L. 2009. Sex-specific, seasonal foraging tactics of adult grey seals (Halichoerus grypus) revealed by state-space analysis. Ecology 90(11):3209-3221.

https://doi.org/10.1890/07-1483.1

Budge, S.M., Springer, A.M., Iverson, S.J., Sheffield, G., and Rosa, C. 2008. Blubber fatty acid composition of bowhead whales, Balaena mysticetus: Implications for diet assessment and ecosystem monitoring. Journal of Experimental Marine Biology and Ecology 359(1):40-46.

https://doi.org/10.1016/j.jembe.2008.02.014

Charif, R.A., Rahaman, A., Muirhead, C.A., Pitzrick, M.S., Warde, A.M., Hall, J., Pyc, C., and Clark, C.W. 2013. Bowhead whale acoustic activity in the southeast Beaufort Sea during late summer 2008-2010. Journal of the Acoustical Society of America 134(6):4323-4334.

https://doi.org/10.1121/1.4824679

Christman, C.L., Citta, J.J., Quakenbush, L.T., Clarke, J.T., Rone, B.K., Shea, R.A., Ferguson, M.C., and Heide-Jørgensen, M.P. 2013. Presence and behavior of bowhead whales (Balaena mysticetus) in the Alaskan Beaufort Sea in July 2011. Polar Biology 36(12):1851-1856. https://doi.org/10.1007/s00300-013-1395-4

Citta, J.J., Quakenbush, L.T., George, J.C., Small, R.J., HeideJørgensen, M.P., Brower, H., Adams, B., and Brower, L. 2012. Winter movements of bowhead whales (Balaena mysticetus) in the Bering Sea. Arctic 65(1):13-34. https://doi.org/10.14430/arctic4162

Citta, J.J., Burns, J.J., Quakenbush, L.T., Vanek, V., George, J.C., Small, R.J., Heide-Jørgenson, M.P., and Brower, H. 2014. Potential for bowhead whale entanglement in cod and crab pot gear in the Bering Sea. Marine Mammal Science 30(2):445-459. https://doi.org/10.1111/mms.12047

Citta, J.J., Quakenbush, L.T., Okkonen, S.R., Druckenmiller, M.L., Maslowski, W., Clement-Kinney, J., George, J.C., et al. 2015. Ecological characteristics of core-use areas used by Bering-Chukchi-Beaufort (BCB) bowhead whales, 2006-2012. Progress in Oceanography 136:201-222. https://doi.org/10.1016/j.pocean.2014.08.012

Clark, C.W., Berchok, C.L., Blackwell, S.B., Hannay, D.E., Jones, J., Ponirakis, D., and Stafford, K.M. 2015. A year in the acoustic world of bowhead whales in the Bering, Chukchi and Beaufort Seas. Progress in Oceanography 136:223-240. https://doi.org/10.1016/j.pocean.2015.05.007 
Conlan, K., Aitken, A., Hendrycks, E., McClelland, C., and Melling, H. 2008. Distribution patterns of Canadian Beaufort Shelf macrobenthos. Journal of Marine Systems 74(3-4): $864-886$.

https://doi.org/10.1016/j.jmarsys.2007.10.002

Conlan, K., Hendrycks, E., Aitken, A., Williams, B., Blasco, S., and Crawford, E. 2013. Macrofaunal biomass distribution on the Canadian Beaufort Shelf. Journal of Marine Systems 127:76-87. https://doi.org/10.1016/j.jmarsys.2013.07.013

Cubbage, J.C., and Calambokidis, J. 1987. Size-class segregation of bowhead whales discerned through aerial stereophotogrammetry. Marine Mammal Science 3(2):179-185. https://doi.org/10.1111/j.1748-7692.1987.tb00160.x

Davis, R.A., Koski, W.R., Richardson, W.J., Evans, C.R., and Alliston, G.W. 1982. Distribution, numbers and productivity of the western Arctic stock of bowhead whales in the eastern Beaufort Sea and Amundsen Gulf, 1981. Unpubl. report for Sohio Petroleum Ltd., Dome Petroleum Ltd., and others, by LGL Research Associates Ltd, Box 457, King City, Ontario L0G 1K0, Canada.

Duong, T. 2007. ks: Kernel density estimation and kernel discriminant analysis for multivariate data in R. Journal of Statistical Software 21(7):1-16.

https://doi.org/10.18637/jss.v021.i07

Duong, T., and Hazelton, M.L. 2005. Cross-validation bandwidth matrices for multivariate kernel density estimation. Scandinavian Journal of Statistics 32(3):485-506. https://doi.org/10.1111/j.1467-9469.2005.00445.x

George, J.C., Bada, J., Zeh, J., Scott, L., Brown, S.E., O’Hara, T., and Suydam, R. 1999. Age and growth estimates of bowhead whales (Balaena mysticetus) via aspartic acid racemization. Canadian Journal of Zoology 77(4):571 - 580.

https://doi.org/10.1139/z99-015

George, J.C., Follmann, E., Zeh, J., Sousa, M., Tarpley, R., Suydam, R., and Horstmann-Dehn, L. 2011. A new way to estimate the age of bowhead whales (Balaena mysticetus) using ovarian corpora counts. Canadian Journal of Zoology 89(9):840 - 852. https://doi.org/10.1139/z11-057

Griffiths, W.B., and Buchanan, R.A. 1982. Characteristics of bowhead feeding areas. In: Richardson, W.J., ed. Behavior, disturbance responses and feeding of bowhead whales (Balaena mysticetus) in the Beaufort Sea, 1980-81. Unpubl. report by LGL Ltd., Toronto, for U.S. Bureau of Land Management, Washington, D.C. NTIS No. PB86-152170. Springfield, Virginia: National Technical Information Service. 347-355.

Griffiths, W.B., and Thomson, D.H. 2002. Species composition, biomass and local distribution of zooplankton relative to water masses in the eastern Alaskan Beaufort Sea. In: Richardson, W.J., and Thomson, D.H., eds. Bowhead whale feeding in the eastern Alaskan Beaufort Sea: Update of scientific and traditional information, Vol. 1. OCS Study MMS 2002-012; LGL Report TA2196-7. Report by LGL Ltd., King City, Ont., for U.S. Minerals Management Service, Anchorage, Alaska and Herndon, Virginia. 5.1-5.43.
Harris, R.E., Elliott, T., and Davis, R.A. 2007. Results of mitigation and monitoring program, Beaufort Span 2-D marine seismic program, in open-water season 2006. Unpubl. report for GX Technology, Houston, Texas 77042, by LGL Ltd., Box 457, King City, Ontario L0G 1K0. 47 p.

Harris, R.E., Lewin, A., Hunter, A., Fitzgerald, M., Davis, A.R., Elliott, T., and Davis, R.A. 2008. Results of mitigation and monitoring program, Beaufort Span 2-D marine seismic program, in open-water season 2007. Unpubl. report for GX Technology, Houston, Texas 77042, by LGL Ltd., Box 457, King City, Ontario L0G $1 \mathrm{~K} 0$.

Harwood, L.A., and Borstad, G.A. 1985. Bowhead whale monitoring study in the southeast Beaufort Sea, July-September 1984. Environmental Studies Revolving Fund Report No. 009. Ottawa: ESRF. 99 p.

Harwood, L.A., Auld, J., Joynt, A., and Moore, S.E. 2009. Distribution of bowhead whales in the SE Beaufort Sea during late summer, 2007-2009. Canadian Science Advisory Secretariat Research Document 2009/111. Ottawa: Fisheries and Oceans Canada. 22 p.

Harwood, L.A., Smith, T.G., Auld, J.C., Melling, H., and Yurkowski, D. 2015. Seasonal movements and diving of ringed seals, Pusa hispida, in the western Canadian Arctic, 1999-2001 and 2010-11. Arctic 68(2):193-209.

https://doi.org/10.14430/arctic4479

Hauser, D.D.W., Laidre, K.L., Suydam, R.S., and Richard, P.R. 2014. Population-specific home ranges and migration timing of Pacific Arctic beluga whales (Delphinapterus leucas). Polar Biology 37(8):1171 - 1183. https://doi.org/10.1007/s00300-014-1510-1

Heide-Jørgensen, M.P., Kleivane, L., Øien, N., Laidre, K.L., and Jensen, M.V., 2001. A new technique for deploying satellite transmitters on baleen whales: Tracking a blue whale (Balaenoptera musculus) in the North Atlantic. Marine Mammal Science 17(4):949-954.

https://doi.org/10.1111/j.1748-7692.2001.tb01309.x

Heide-Jørgensen, M.P., Laidre, K.L., Wiig, Ø., Jensen, M.V., Dueck, L., Maiers, L.D., Schmidt, H.C., and Hobbs, R.C. 2003. From Greenland to Canada in ten days: Tracks of bowhead whales, Balaena mysticetus, across Baffin Bay. Arctic 56(1):21-31.

https://doi.org/10.14430/arctic599

Heide-Jørgensen, M.P., Laidre, K.L., Quakenbush, L.T., and Citta, J.J. 2012. The Northwest Passage opens for bowhead whales. Biology Letters 8(2):270-273. https://doi.org/10.1098/rsbl.2011.0731

Jakobsson, M., Mayer, L., Coakley, B., Dowdeswell, J.A., Forbes, S., Fridman, B., Hodnesdal, H., et al. 2012. The international bathymetric chart of the Arctic Ocean (IBCAO) Version 3.0. Geophysical Research Letters 39, L12609.

https://doi.org/10.1029/2012GL052219

Jonsen, I.D., Flemming, J.M., and Myers, R.A. 2005. Robust state-space modeling of animal movement data. Ecology 86(11):2874-2880.

https://doi.org/10.1890/04-1852 
Koski, W.R., and Miller, G.W. 2009. Habitat use by different size classes of bowhead whales in the central Beaufort Sea during late summer and autumn. Arctic 62(2):137-150. https://doi.org/10.14430/arctic127

Koski, W.R., Miller, G.W., and Davis, R.A. 1988. The potential effects of tanker traffic on the bowhead whale in the Beaufort Sea. Environmental Studies 58. Report by LGL Limited, King City, Ontario, for the Department of Indian Affairs and Northern Development, Hull, Quebec. NTIS MIC-90-04552. Springfield, Virginia: National Technical Information Service. $150 \mathrm{p}$.

Koski, W.R., Davis, R.A., Miller, G.W., and Withrow, D.E. 1993. Reproduction. In: Burns, J.J., Montague, J.J., and Cowles, C.J., eds. The bowhead whale. Society for Marine Mammalogy, Special Publication No. 2. Lawrence, Kansas: Allen Press. 239-274.

Lindberg, M.S., and Walker, J. 2007. Satellite telemetry in avian research and management: Sample size considerations. Journal of Wildlife Management 71(3):1002-1009.

https://doi.org/10.2193/2005-696

Lowry, L.F. 1993. Foods and feeding ecology. In: Burns, J.J., Montague, J.J., and Cowles, C.J., eds. The bowhead whale. Society for Marine Mammalogy, Special Publication No. 2. Lawrence, Kansas: Allen Press. 201-238.

Lowry, L.F., Sheffield, G., and George, J.C. 2004. Bowhead whale feeding in the Alaskan Beaufort Sea based on stomach content analyses. Journal of Cetacean Research and Management 6(3):215-223.

Mate, B.R., Krutzikowsky, G.K., and Winsor, M.H. 2000. Satellite-monitored movements of radio-tagged bowhead whales in the Beaufort and Chukchi Seas during the latesummer feeding season and fall migration. Canadian Journal of Zoology 78(7):1168-1181. https://doi.org/10.1139/z00-045

Miller, G.W., Moulton, V.D., Davis, R.A., Holst, M., Millman, P., McGillivray, A., and Hannay, D. 2005. Monitoring seismic effects on marine mammals-southeastern Beaufort Sea, 2001-2002. In: Armsworthy, S.L., Cranford, P.J., and Lee, K., eds. Offshore oil and gas environmental effects monitoring: Approaches and technologies. Columbus, Ohio: Battelle Press. $511-542$.

Moore, S.E., and Reeves, R.R. 1993. Distribution and movement. In: Burns, J.J., Montague, J.J., and Cowles, C.J., eds. The bowhead whale. Society for Marine Mammalogy, Special Publication No. 2. Lawrence, Kansas: Allen Press. 313-386.

Morin, P.A., Nestler, A., Rubio-Cisneros, N.T., Robertson, K.M., and Mesnick, S.L. 2005. Interfamilial characterization of a region of the ZFX and ZFY genes facilitates sex determination in cetaceans and other mammals. Molecular Ecology 14(10):3275-3286. https://doi.org/10.1111/j.1365-294X.2005.02651.x

Okkonen, S.R., Ashjian, C.J., Campbell, R.G., Clarke, J.T., Moore, S.E., and Taylor, K.D. 2011. Satellite observations of circulation features associated with a bowhead whale feeding 'hotspot' near Barrow, Alaska. Remote Sensing of Environment 115(8):2168-2174.

https://doi.org/10.1016/j.rse.2011.04.024
Paulic, J.E., Bartzen, B., Bennett, R., Conlan, K., Harwood, L., Howland, K., Kostylev, V., et al. 2012. Ecosystem overview report for the Darnley Bay Area of Interest (AOI). Canadian Science Advisory Secretariat Research Document 2011/062. Ottawa: Fisheries and Oceans Canada. 63 p.

Pomerleau, C., Ferguson, S.H., and Walkusz, W. 2011. Stomach contents of bowhead whales (Balaena mysticetus) from four locations in the Canadian Arctic. Polar Biology 34(4):615-620. https://doi.org/10.1007/s00300-010-0914-9

Quakenbush, L.T., Citta, J.J., George, J.C., Small, R.J., and HeideJørgensen, M.P. 2010a. Fall and winter movements of bowhead whales (Balaena mysticetus) in the Chukchi Sea and within a potential petroleum development area. Arctic 63(3):289-307. https://doi.org/10.14430/arctic1493

Quakenbush, L.T., Small, R.J., and Citta, J.J. 2010b. Satellite tracking of Western Arctic bowhead whales: Final report. OCS Study BOEM 2010-033. Anchorage: U.S. Department of the Interior, Bureau of Ocean Energy Management. 65 p. + appendices.

Quakenbush, L.T., Citta, J., George, J.C., Heide-Jørgensen, M.P., Small, R., Brower, H., Harwood, L., et al. 2012. Seasonal movements of the Bering-Chukchi-Beaufort stock of bowhead whales: 2006-2011 satellite telemetry results. Report to the International Whaling Commission Scientific Committee SC/64/BRG1. 22 p.

Quakenbush, L.T., Small, R.J., and Citta, J.J. 2013. Satellite tracking of bowhead whales: Movements and analysis from 2006 to 2012. OCS Study BOEM 2013-01110. Anchorage: U.S. Department of the Interior, Bureau of Ocean Energy Management. 60 p. + appendices.

R Development Core Team 2010. R: A language and environment for statistical computing. Vienna, Austria: R Foundation for Statistical Computing. http://www.R-project.org/

Richard, P.R., Martin, A.R., and Orr, J.R. 2001. Summer and autumn movements of belugas of the eastern Beaufort Sea stock. Arctic 54(3):223-236.

https://doi.org/10.14430/arctic783

Richardson, W.J., and Thomson, D.H., eds. 2002. Bowhead whale feeding in the eastern Alaskan Beaufort Sea: Update of scientific and traditional information, 2 vols. OCS Study MMS 2002-012; LGL Report TA2196-7. Report by LGL Ltd., King City, Ontario, for the U.S. Minerals Management Service, Anchorage, Alaska and Herndon, Virginia.

Richardson, W.J., Davis, R.A., Evans, C.R., Ljungblad, D.K., and Norton, P. 1987. Summer distribution of bowhead whales, Balaena mysticetus, relative to oil industry activities in the Canadian Beaufort Sea, 1980-84. Arctic 40(2):93-104. https://doi.org/10.14430/arctic1753

Silverman, B.W. 1986. Density estimation for statistics and data analysis. London: Chapman and Hall. 
Thomson, D.H., Fissel, D.B., Marko, J.R., Davis, R.A., and Borstad, G.A. 1986. Distribution of bowhead whales in relation to hydro-meteorological events in the Beaufort Sea. Environmental Studies Revolving Funds Report No. 028. Ottawa: ESRF.

http://publications.gc.ca/collections/collection_2016/one-neb/ NE22-4-028-eng.pdf

Walkusz, W., Paulić, J.E., Kwaśniewski, S., Williams, W.J., Wong, S., and Papst, M.H. 2010. Distribution, diversity and biomass of summer zooplankton from the coastal Canadian Beaufort Sea. Polar Biology 33(3):321 - 335 . https://doi.org/10.1007/s00300-009-0708-0

Walkusz, W., Williams, W.J., Harwood, L.A., Moore, S.E., Stewart, B.E., and Kwasniewski, S. 2012. Composition, biomass and energetic content of biota in the vicinity of feeding bowhead whales (Balaena mysticetus) in the Cape Bathurst upwelling region (south eastern Beaufort Sea). DeepSea Research Part I 69:25-35. https://doi.org/10.1016/j.dsr.2012.05.016
Wand, M.P., and Jones, M.C. 1995. Kernel smoothing. London: Chapman and Hall.

Williams, W.J., and Carmack, E.C. 2008. Combined effect of wind-forcing and isobaths divergence on upwelling at Cape Bathurst, Beaufort Sea. Journal of Marine Research 66(5):645-663. https://doi.org/10.1357/002224008787536808

Worton, B.J. 1989. Kernel methods for estimating the utilization distribution in home-range studies. Ecology 70(1):164-168. https://doi.org/10.2307/1938423

Würsig, B., Dorsey, E.M., Fraker, M.A., Payne, R.S., and Richardson, W.J. 1985. Behavior of bowhead whales, Balaena mysticetus, summering in the Beaufort Sea: A description. Fishery Bulletin 83(3):357-377.

Würsig, B., Dorsey, E.M., Richardson, W.J., and Wells, R.S. 1989. Feeding, aerial and play behaviour of the bowhead whale, Balaena mysticetus, summering in the Beaufort Sea. Aquatic Mammals 15(1):27-37. 